\title{
Kelet-mediterráneumi gázkincs: a ciprusi válság új dimenzióban
}

Törökország 2019 tavaszán fúróhajókat küldött a ciprusi Különleges Gazdasági Övezetbe (EEZ). Mindez nemzetközi válsághoz vezetett, felhívván a figyelmet a Földközitenger keleti medencéjében zajló gázvitára. A tanulmány a vita és okainak elemzésére tesz kísérletet. A Ciprus és Törökország közötti feszültségnek számos oka van, idetartozik a szigetország 1974 óta tartó megosztottsága (az északi részén létrejött a csak Törökország által elismert Észak-Ciprusi Török Köztársaság, KKTC). A probléma megoldatlansága további feszültségeket eredményezett az EEZ-t és a befolyó jövedelmek elosztását illetően. Mivel a 2000-es évek közepétől a kutatások sikerrel zárultak, és a Ciprustól délre elterülő vizek alatt számos gázmezőt tártak fel, a jogai biztosítása érdekében egy konfrontatívabb politikára késztették Törökországot és a KKTC-t. Végezetül, tágabb kontextusban vizsgálva a kérdés komoly regionális dimenzióval is rendelkezik: az utóbbi 10-15 évben további jelentős készleteket találtak az izraeli és az egyiptomi EEZ-ben, lehetővé téve, hogy ezek az országok exportőrökké váljanak. A hasonló helyzetben lévő Ciprus (élvezvén Görögország támogatását) elkezdte támogatni az energiapolitikai együttmüködést, ami a két másik ország és Törökország közötti rossz kapcsolatból is fakadóan korlátozza Ankara mozgásterét a régióban.

Kulcsszavak: Törökország, Ciprus, Kelet-Mediterráneum, energia, geoplitika

\section{Egeresi Zoltán: Gas Reserves in the Eastern Mediterranean: New Dimension in the Cyprus Crisis}

The paper aims to analyse the ongoing gas dispute in the Eastern Mediterranean. Turkey sent drilling ships in Cyprus's EEZ in the spring of 2019 which escalated to a diplomatic crisis. The tensions between the two countries have multiple causes, and the paper intends to examine them at local and regional level. Firstly, the Turkish intervention in 1974 led to the partition of the island and the establishment of the Turkish Republic of Northern Cyprus (recognised only by Ankara). Despite the efforts, this problem has not been solved yet leading to territorial disputes concerning the use and the extent of the Exclusive Economic Zone of the island. Secondly, the drilling activities since the mid-2000s were successful in the South by discovering several gas fields which pushed Turkey and the Turkish Republic of Northern Cyprus to pursue a more confrontative foreign policy in order to assure their rights. Thirdly, during the last 10-15 years, large reserves were found in the Egyptian and Israeli EEZ as well, opening the opportunity for these states to become gas exporters. Cyprus (and Greece) began to support the energy cooperation between these countries which (taking into consideration their problems with Ankara) limits Turkey's room for manoeuvre in the region.

Keywords: Turkey, Cyprus, Eastern Mediterranean, energy, geopolitics 


\section{Bevezetés}

Július-augusztus folyamán Törökország fúróhajókat küldött a Ciprus szigete körüli vizekre, ami a szigetország és az EU, illetve az Egyesült Államok tiltakozását váltotta ki. A ciprusi kormány állami szuverenitásának megsértésével vádolta meg Ankarát. Törökország elutasította a vádat, mondván, hogy a ciprusi törökök érdekeit védi, és hajlandó akár fegyverrel is megvédeni a hajókat.

A diplomáciai konfliktus és kardcsörte a fúróhajókat és a tengeri övezeteket illetően azonban egyáltalán nem újdonság a Ciprus körüli vizeken: amióta 2011-ben a szigettől délre jelentős földgázlelőhelyeket tártak fel, azonnal felértékelődött a tengeri határok szerepe.

Az állandó konfliktus persze még régebbre vezethető vissza, a sziget 1974-es megosztottságát mind a mai napig nem sikerült rendezni. Törökország nem ismeri el a déli szigetrészt, miközben a sziget északi területeit magában foglaló Észak-ciprusi Török Köztársaságot a nemzetközi közösség nem tekinti legitim államalakulatnak. Ez a több évtizedes szembenállás a 2010-es évektől új dimenzióval egészült ki, amely ráadásul túlmutat Cipruson: a Földközi-tenger keleti medencéjében újabb és újabb földgázmezöket tártak fel az előző években (például az egyiptomi Zorh mező vagy az izreaeli Tamar és Leviathan), és ez egy ciprusi-egyiptomi-izraeli-görög együttmüködés létrejöttéhez vezetett, ami pedig több tényező közrejátszása mellett Törökország régiós elszigetelődésében is szerepet játszik.

\section{Ciprus megosztottsága: a jelenlegi probléma dióhéjban}

A probléma megértéséhez érdemes kissé visszatekinteni a szigetország történetét illetően. Az oszmán csapatok 1570-ben foglalták el, majd évszázadokra berendezkedtek a túlnyomórészt görög többségü szárazulaton. Az évszázadok alatt történő anatóliai betelepülésnek köszönhetően jelentős török kisebbség alakult ki a szigeten.

Ciprus 1878-ban brit fennhatóság alá került. A második világháború után megélénkültek a szigeten az elszakadási mozgalmak, amelyek tüntetésekhez, majd pedig olvasattól függően terrorcselekményekhez vagy felszabadító akciókhoz vezettek az EOKA nevü ciprusi görög szervezet részéről. Az EOKA ráadásul nemcsak függetlenségért, de a Görögországgal történő egyesülésért (enoszisz) is síkra szállt. Miután Görögország (Törökországgal együtt) NATO-tag lett 1952-ben, nyíltan kezdte támogatni a ciprusiakat. A görög fegyveres akciók persze nemcsak az Egyesült Királyság, de a török kisebbség ellenkezését is kiváltották. Az utóbbiak előbb a sziget brit uralom alatt maradását, később megosztását (taksim) preferálták. ${ }^{1}$ Ebben a helyzetben London az oszd meg és uralkodj politikáját választotta: 1955-től meghívta Törökországot és Görögországot a sziget státuszának rendezésére hivatott tárgyalásokra. ${ }^{2}$

Kacziba Péter: Többség kisebbségi, kisebbség többségi támogatással: Az anyaországi beavatkozás szerepe Cipruson. In: Szalai Máté - Wagner Péter: A többség-kisebbség dinamika szerepe a közel-keleti konfliktusokban, Magyarország: Külügyi és Külgazdasági Intézet, Budapest, 2019, 58-80. o.; különösen 61-62. o.

Ezzel a ciprusi kérdés komoly belpolitikai témává vált Törökországban, s vezetett az 1955. szeptemberi eseményekhez, amikor a feltüzelt tömeg az isztambuli görögök boltjait támadta meg. Az incidens pedig utat nyitott az isztambuli görögség gyors emigrációjához Görögországba. 
A felek végül az 1959-es zürichi és londoni egyezményben rendezték a sziget státuszát: az Egyesült Királyság egy néhány négyzetkilométeres katonai támaszpont megtartása mellett kivonult a szigetről, amelynek megtiltották az egyesülést Görögországgal és Törökországgal egyaránt. Ugyanakkor az Egyesült Királyságon kívül a két említett állam a sziget státuszát garantáló hatalom lett, egyben felhatalmazást kaptak arra, hogy egyrészt érvényt szerezzenek a megállapodásnak, másrészt fellépjenek a görög vagy a török csoportok védelmében. ${ }^{3}$ A sziget alkotmánya szerint - amelyről szintén a szerződés rendelkezett - az ország államföjének görögnek, alelnökének töröknek kellett lennie, akik széles vétójogkörökkel rendelkeztek. A törökség mintegy 20\%-os népességen belüli arányához képest nagylelkủen több parlamenti mandátumot kapott. ${ }^{4}$

Összességében ezek a tényezők a Földközi-tenger keleti medencéjében egy újabb puskaporos hordót teremtettek, amely a maga lappangó etnikai konfliktusával csak a robbanásra várt. Erre aztán 1963 végén került sor, amelynek során a szigeten elszórtan élő török kisebbség megerösítette az enklávéit, illetve Ankara majdnem lerohanta a szigetet - az intervenciótól csak az amerikai elnök határozott beavatkozása (úgynevezett Johnson-levél) tudta eltántorítani. Ugyan a háborút sikerült elkerülni, de nem oldódtak meg a két közösség közötti problémák.

Az újabb fordulatot az hozta, hogy Athén támogatásával 1974-ben katonatisztek egy csoportja puccsot hajtott végre a ciprusi elnök Makariosz érsek ellen, és kimondta a sziget egyesülését Görögországgal. A török válasz nem maradt el: Bülent Ecevit akkori török miniszterelnök haladéktalanul engedélyt adott a katonai intervencióra. Az első hullám már meghozta a sikert: a puccsisták elmenekültek (sőt, a görögországi katonai junta is összeomlott, ezzel utat nyitva a demokratizálódásra), a hatalom a helyiek kezébe került. Viszont a fegyverszünet nem tartott sokáig, és a nemzetközi közösség tiltakozása ellenére Törökország egy második hadjáratban, augusztus folyamán újabb területeket foglalt el, így összességében a sziget 37\%-a került ellenőrzése alá. Az északi részt hamarosan a senki földjévé váló úgynevezett Attila-vonal választotta le a délitől, miközben a törökök északra, a görögök délre költöztek.

A török részen 1983-ban kikiáltották az - azóta is csak Ankara által elismert - Északciprusi Török Köztársaságot (KKTC), ezzel a sziget két entitásra szakadt, az északi részen mintegy 30 ezer török katonával. A török ciprióta entitás erőteljesen függ a török anyaállamtól, amely jelentős támogatást nyújt a sziget gazdasága számára. Az intervenció után Anatóliából jelentős népesség települt át (a lakosság kb. 30\%-a napjainkban), illetve a területen megjelentek a törökországi cégek is. Szintén fontos tényezö lett, hogy az anyaországi egyetemek közül számos létesített kampuszt, így pezsgő diákéletet és plusz bevételforrást hoztak a szigetrészre. Ezzel együtt a török ellenőrzés meghatározó, a KKTC jegybankja elnökének például török állampolgárnak kell lennie. Emellett a török nagykövetek is jellemzően aktívan igyekeznek kivenni részüket az állam életének alakításában.

KACZIBA: $i . m ., 62$.

Constitution of Cyprus, 1960, [online]. Forrás: UNPan1 [2019. 08. 03.] 
Athén a török anyaországhoz hasonlóan szintén megpróbálta támogatni a görög cipriótákat - noha a sziget megosztását eredményező 1974-es puccs miatt erősen csökkent a befolyása. A következő évtizedekben Görögország a szigethez hasonlóan lemondott az egyesítésről, és a török beavatkozás jogtalanságának propagálására helyezte a hangsúlyt. Az 1990-es évektől kezdve pedig egyre inkább a sziget uniós tagságának elérése lett a célja, amit sikeresen el is ért 2004-ben. ${ }^{5}$

Törökország és a Ciprusi Köztársaság kapcsolata még bonyolultabb: Ankara nem ismeri el a görög ciprióta államalakulat létét (ennek köszönhetően Nicosia kérésére többet is befagyasztottak Törökország uniós csatlakozási tárgyalási fejezetei közül), s ezzel együtt a török ciprióták érdekeit igyekszik képviselni.

A sziget újraegyesítése érdekében már a török intervenció utáni években megindultak a tárgyalások ENSZ-közvetítéssel. Köszönhetően annak, hogy a Ciprusi Köztársaság az 1997-es luxemburgi csúcson, Törökország pedig az 1999-es helsinki csúcson kapta meg az uniós tagjelölt státuszt, a sziget egyesítése is fontosabbá vált. A felek a legközelebb a probléma megoldásához 2004-ben jutottak, amikor Kofi Annan ENSZ-fötitkár újraegyesítési javaslatáról népszavazást rendeztek. Ezt a török ciprióták többsége támogatta, míg a görög rész nemmel szavazott, így ez a lehetőség meghiúsult. A Ciprusi Köztársaság a rendezés nélkül lett az EU tagja, ami Törökország uniós csatlakozási törekvéseit akadályozza, illetve a sziget körüli vitákba bevont egy sokkal nagyobb entitást is.

Kevés eredménnyel, de a sziget egyesítéséről szóló tárgyalások folytatódtak az ENSZ égisze alatt 2004 után is. Ezek dinamikája viszont a 2000-es évek végétől kiegészült a Ciprus körüli földgázmezők kérdésével is. 2014-ben az újraegyesítési tárgyalásokat felfüggesztették, majd azok ismét újraindultak. A legutóbbi évek ígéretes fordulóit követően a Svájc területén található Crans-Montanában folyó tárgyalások 2017 júniusában zátonyra futottak. A bizónális és bikommunális megoldást szorgalmazó tárgyalásokon végül a két fél nem tudott megegyezni a területi módosításokról és a biztonsági garanciákról. ${ }^{6}$

\section{A kelet-mediterráneumi gázkincs, Ciprus és a geopolitika}

A több évtizedes ciprusi vita a 2010-es évek elejétől új dimenzióval egészült ki. Köszönhetően a több külföldi vállalat bevonásával (Noble Energy, ENI, Exxon Mobil stb.) indított kutatások eredményeinek, teljes mértékben átalakult a Kelet-Mediterráneum energiapolitikai térképe. 2009-2015 folyamán ugyanis több jelentős gázmezőt sikerült feltárni az Egyiptom, Izrael és Ciprus által határolt tengerrészen. Ráadásul ezek jelentős készletek: az egyiptomi Zohr 850 milliárd $\mathrm{m}^{3}$-es, az izraeli Leviathán 500-620 milliárd $\mathrm{m}^{3}$-es ${ }^{7}$ és a Tamar 200 milliárd $\mathrm{m}^{3}$-es gázlelőhelyek, hogy csak a legjelentősebbeket említsük. Becslések szerint ezen

KACZIBA: $i$. $m$. 68-69.

Cyprus reunification talks collapse, U.N. chief ,very sorry', [online], 2017. 07. 07. Forrás: Reuters [2019. 07. 25.]

Israel: Differing opinions on the Leviathan field size, [online], 2016. 06. 06. Forrás: Offshoreenergytoday.com [2019. 07. 31.] 
túlmenően még további jelentős szénhidrogénkincs található a régióban, ami feltárásra vár. Az utóbbi években újabb lendületet kapó kutatások hozták is az eredményeket, így például 2019 áprilisában a görög Energean vállalat tárt fel kisebb, pár tíz milliárd köbméternyi gázt tartalmazó mezőket az izraeli partoktól nem messze. ${ }^{8}$

Ezen felfedezések hatása óriási volt. Az eddig behozatalra szoruló országok lehetőséget kaptak, hogy gázexportőrökké váljanak. A Zohr-mezők 2015-ös feltárásával Egyiptom hirtelen energia-nagyhatalommá vált, erre az évre már önellátó, $s$ az előzetes várakozások szerint 2019 végéig megkezdik a gázexportot. Köszönhetően annak, hogy két jelentős LNG-terminállal rendelkezik, kiváló lehetősége van arra, hogy gázvezetékek nélkül szállítson az európai piacra, valamint a régiós földgázelosztóvá váljon. A két terminálban részesedéssel rendelkező Royal Dutch Shell és Eni vállalatok nagy erőfeszítéseket tesznek, hogy az év végéig mindkét létesítmény teljes kapacitáson müködjön. Ezáltal nemcsak az egyiptomi földgázt lehet cseppfolyósítani és értékesíteni az európai piacon, hanem a környező, más országokét is, ami mind Izrael, mind Ciprus számára lehetőségekkel kecsegtet. ${ }^{9}$ A hatalmas lelőhelyeinek köszönhetően januárban Jordániával is megállapodást kötött az egyiptomi kormány arról, hogy az ország földgázszükségletének felét biztosítja 2019-ben - ezt éppen gázvezeték segítségével. ${ }^{10}$

A hirtelen szintén exportőrré váló Izrael (a hatalmas Leviathan-mező gázkészletének kitermelése az év végéig szintén kezdetét veszi, a Tamar kitermelése már 2013 óta tart) szerződést írt alá Egyiptommal évi 7 milliárd köbméter gáz szállításáról. A megállapodás szerint novembertől a Tamar- és Leviathan-mezőkből érkező gáz egy része az egyiptomi piacra, más része pedig újraértékesítésre kerül. ${ }^{11}$

Nemcsak Izrael és Egyiptom, de Ciprus is szerencsés volt: több fúrás is sikerrel járt, amit elősegített, hogy e két állammal a 2000-es években rendezték a kizárólagos gazdasági övezetek (EEZ) ${ }^{12}$ megállapítását. A szigettől délre lévő területen található, nem vagy „korlátozottan" vitatott hovatartozású blokkok (lásd később) egy részében az utóbbi nyolc év kutatómunkája már hozott eredményt.

\footnotetext{
Significant natural gas discovery made off israel's shore, [online], 2019. 05. 15. Forrás: Jerusalem Post [2019. 07. 31.] Egypt Looks to Offshore Gas Field for Growth and Influence, [online], 2019. 03. 11. Forrás: The New York Times [2019. 07. 30.]

10 Egypt to supply Kingdom with half of its gas needs this year, [online], 2019. 01. 13. Forrás: Jordan Times [2019. 07. 30.]

11 Israel will start exporting natural gas to Egypt this year, [online], 2019. 07. 25. Forrás: Aljazeera [2019. 08. 01.]

12 Az EEZ vagy kizárólagos gazdasági övezet 24-200 tengeri mérföld távolságban elhelyezkedő terület, ami a parti tenger (partvonaltól 12 tengeri mérföld) és a csatlakozó övezet (12-24 tengeri mérföld) utáni térséget jelöli, amely övezetben az adott állam az erőforrások fölött rendelkezik.
} 


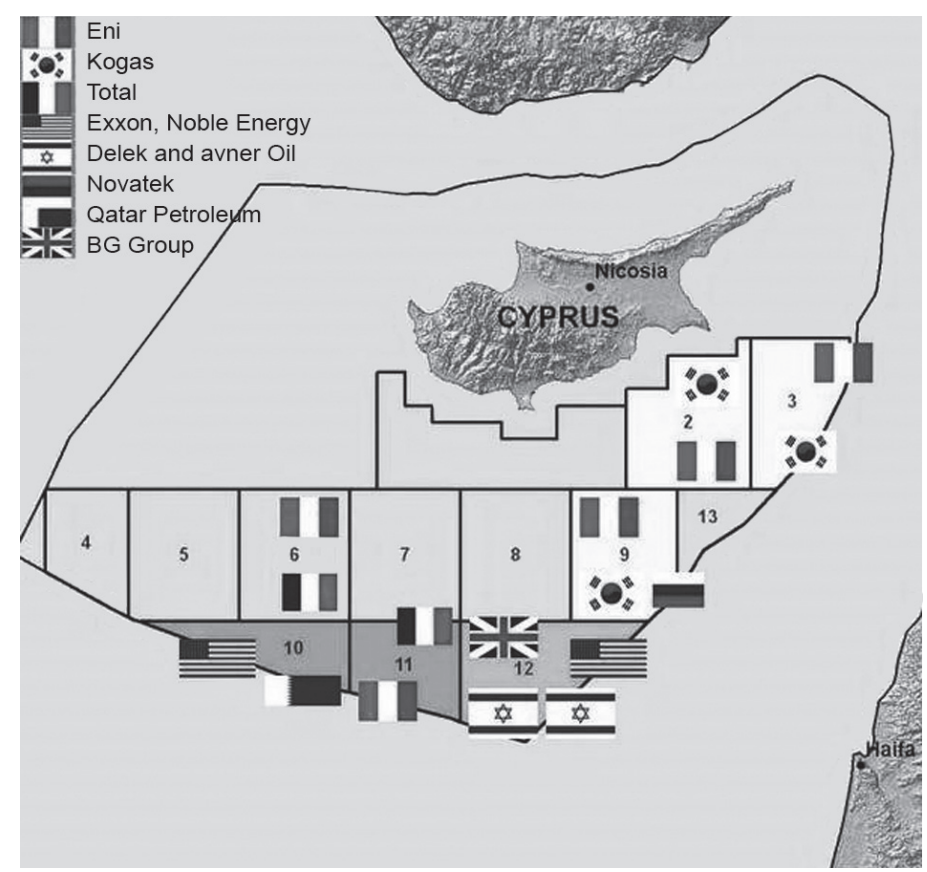

1. ábra: A Ciprustól délre elterülő blokkok és az azokban tevékenykedő nemzetközi vállalatok

Forrás: Blessing or curse for the divided island? [online], 2018. 12. 21. Forrás: Voxeurop [2019. 01. 12.].

Eddig három jelentős mezőt sikerült feltárni. Az elsőt még 2011-ben, a mintegy 140 milliárd $\mathrm{m}^{3}$ földgázt rejtő Afrodité mezőt (12-es blokk), a másodikat az ENI találta meg a 6-os blokkban (Calypso-mezö, a becslések szerint 170-230 milliárd m³ 2018 elején. ${ }^{13}$ Idén februárban pedig az Afroditénél is nagyobb mezőre bukkantak az Exxon Mobil fúróhajói: a Glaucus-1 nevet viselő területen (10-es blokk) mintegy 140-230 milliárd m³ -nyi földgáz található az eddigi becslések szerint. ${ }^{14}$ Ezzel szigettől délre elterülő gázkincs valós nagysága 450-600 milliárd $\mathrm{m}^{3}$ földgáz lehet. A kutatások még folynak, és akár további jelentős eredményekkel járhatnak.

A szigetországtól délre elterülő blokkokban végzett sikeres fúrások Ciprust is hasonló helyzetbe hozták, mint Egyiptomot és Izraelt: megadták a lehetőséget, hogy megfelelő infrastrukturális beruházásokkal energetikai nagyhatalom legyen. A 2010-es évek elejének gazdasági nehézségeinek tükrében (lásd: görög válság begyürüzése) kifejezetten ígéretes lehetőséget jelentettek a feltárások.

Mindezek együttesen oda vezettek, hogy a három ország kapcsolata jelentősen javult, ${ }^{15}$ s megindult egy szorosabb energetikai együttmüködés kiépítése, amibe már Athén is beszállt - hiszen az exportra termelö országok számára kulcskérdés, hogy eljusson az európai

13 Eni made important gas discovery in block 6 (updated), [online], 2018. 02. 08. Forrás: Cyprus Mail [2019. 07. 29.]

14 Exxon's Cyprus gas discovery adds another giant to East Med collection, [online], 2019. 02. 28. Forrás: Reuters [2019. 07. 31.]

15 Ciprus ráadásul 2003-ban Egyiptommal, 2007-ben Libanonnal, 2010-ben pedig Izraellel kötötte meg az EEZ-k delimitciójára vonatkozó szerződéseket. 
piacokra a földgázuk, amiben Görögország szívesen eljátszaná a tranzitország szerepét. Ennek megfelelően Görögország-Ciprus-Izrael, illetve Görögország-Ciprus-Egyiptom részvételével háromoldalú tárgyalások indultak meg. Athén ezzel együtt az utóbbi években jelentősen javította pozícióit a térségben, és sikerült rendkívül jó viszonyt kiépítenie az Egyesült Államokkal. ${ }^{16}$

Igy nem véletlen, hogy föként Athén ösztönzésének köszönhetően rendezték meg az első Görögország-Ciprus-Izrael találkozót 2016 legelején. Ezt azóta további négy találkozó követte. Az eredetileg föleg energetikai kooperációra fókuszáló fórum mára egy sokkal szélesebb egyeztetési platformmá vált, így a legutóbbi, 2018 decemberében rendezett alkalmon már az innováció és a kiberbiztonság is napirendre került. A felek az USA támogatása mellett felállítottak Nicosiában egy állandó titkárságot, ezzel újabb lépést téve a háromoldalú találkozók intézményesülése felé.

Az Egyiptom, Görögország és Ciprus részvételével zajló találkozók szintén hasonló utat jártak be. A már a hatodik alkalmon is túl lévő együttmüködés szintén több területre terjed ki, s ugyanígy Cipruson rendelkezik állandó titkársággal. Az együttműködés itt is gyümölcsözőnek tűnik, mivel Nicosia és Athén az EU-ban támogathatja az egyiptomi érdekeket, miközben előbbiek Afrika felé találtak egy biztos támaszt.

A régiós energetikai együttmüködés ebben az évben újabb szinten lépett: 2019 januárjában a Ciprusi Köztársaság, Egyiptom, Görögország, Izrael, Jordánia, Olaszország és Palesztin Hatóság részvételével találkozót tartottak Kairóban, amelynek keretében megegyeztek, hogy egy regionális hatóságot (Eastern Mediterranean Gas Forum) hoznak létre az energetikai kooperáció koordinálására. ${ }^{17}$

Feltűnő, hogy négy (öt) ország kimaradt a meghívottak közül: Szíria, Líbia, Libanon, Törökország (illetve a KKTC) nem vett részt a fórumon. A hiányzásuk a KeletMediterráneum medencéjének középső és északi részét érintő vitákra vezethető vissza. A szíriai háború miatt Szíria kizárólagos gazdasági övezetében el sem kezdődhettek a kutatások, illetve a háború lezárásáig kétséges, hogy Damaszkusz képes lenne-e egyáltalán foglalkozni az üggyel. Líbiával hasonló a helyzet: az ország területén jelenleg több hatalom is létezik, amelyek versengenek a kizárólagos irányításért.

Ami Libanont illeti, a közel-keleti ország nehezményezi a ciprusi-izraeli tengeri határ kijelölését, és azzal vádolja Tel-Avivot, hogy közel $1000 \mathrm{~km}^{2}$-nyi területet vett el tőle. Bejrút ezzel pedig nehezíti a határsávban lévő területek feltárását, és addig nem hajlandó ratifikálni a Ciprussal kötött delimitációs szerződést, amíg az nem tárgyalja újra az Izraellel kötött szerződését - amiről az utóbbi természetesen hallani sem akar. Így a tradicionálisan jó ciprusi-libanoni kapcsolatok ellenére Nicosia lehetetlen helyzetbe került, és diplomáciai eröfeszítései ellenére sem tudja rábírni a két országot a vita rendezésére. A patthelyzet - ezen a fronton is - állandósult.

Ennél sokkal komolyabb gondot okoznak a sziget megosztottságából fakadó problémák. A jelentős gázvagyon kiaknázása az első perctől feszültséget generált a sziget északi és déli fele, illetve ezzel együtt Törökország között. A Ciprusi Köztársaság, amely az 1960-ban függetlenné vált sziget jogos örökösének tartja magát, és a nemzetközi közösség is elismer,

16 Dimitar Bechev: Greece Is Getting Good at Geopolitics, [online], 2019. 07. 25. Forrás: Foreign Policy [2019. 08. 01.]

17 Eastern Mediterranean countries to form regional gas market, [online], 2019. 01. 14. Forrás: Reutres [2019. 07. 31.] 
belügynek tekinti a gázmezők kérdését (illetve az alkudozást erről a török cipriótákkal). Nem zárkózik el a tárgyalásoktól, azonban minden kutatási akciót a saját szuverenitásának megsértéseként értelmez. ${ }^{18}$

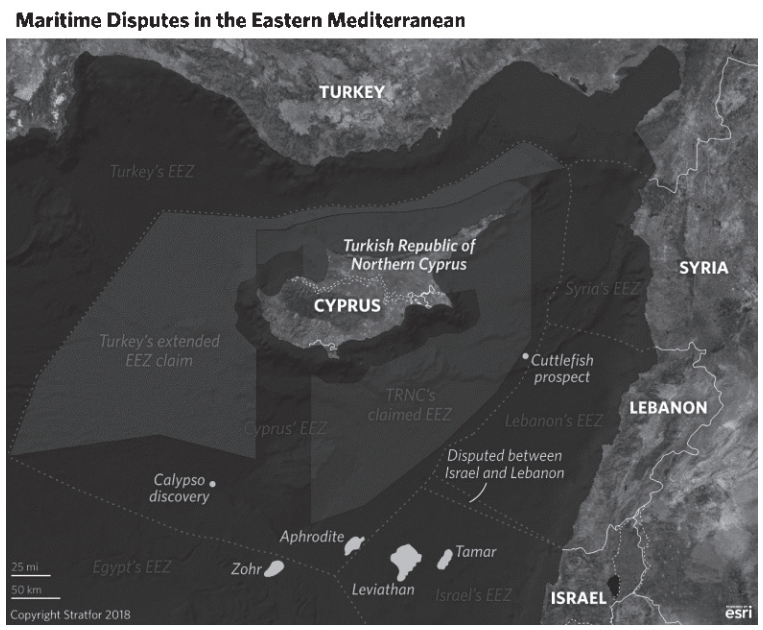

\section{2. ábra: A kelet-mediterráneumi gázmezők és területi viták.}

Forrás: Turkey, Cyprus: The Eastern Mediterranean Heats Up Over Drilling, [online], 2019. 05. 07. Forrás: Stratfor [2019. 07. 30.].

A ciprusi törökök ezzel szemben úgy vélik, hogy a gázlelőhelyek közösek, a belőlük származó jövedelemből mindkét félnek részesednie kell. Ennek megfelelően egy közös felügyelö szerv hatáskörébe utalnák a kérdést, akár nemzetközi szereplők, így az ENSZ és az EU bevonásával. Ez utóbbira már többször is tettek javaslatot: 2011-ben és 2012-ben, illetve legutóbb 2019 júliusában. ${ }^{19} \mathrm{Ez}$ utóbbi ráadásul nemcsak a gazdasági kérdésekbe történő beleszólást engedne, hanem egyszerre nemzetközi jogi státuszt is adna a KKTC-nek - amit Nicosia elvet.

A ciprusi kizárólagos gazdasági övezet lehatárolása érdekében Libanonnal, Izraellel és Egyiptommal megkötött szerződések mintájára Törökország a KKTC-vel kötött delimitációs egyezményt 2011-ben. Ennek értelmében a Ciprusi Köztársaság gazdasági övezetének mintegy felét magának vindikálja a ciprióta török kormány, ideértve az 1, 2, 3, 8, 9, 12 és 13-as blokkokat. ${ }^{20}$ Azonban a ciprióta törökök és görögök között húzódó vitán túlmenően Törökország is jelentős területeket követel magának. Ankara véleménye szerint számára jóval nagyobb kizárólagos gazdasági övezet járna, mint Ciprusnak, amelynek szigetként Törökország szerint nem jár a 200 km-es sávig terjedő övezet (Törökország nem ratifikálta az ENSZ 1982-es Tengerjogi Egyezményét - UNCLOS). Így a Nicosiának az UNCLOS

18 KaCzıBA Péter: A ciprusi földgázkincs feltárásának bel- és külpolitikai sajátosságai, Külügyi Szemle, 12. évf., 2013/4 149-171., különösen 155.

19 Interjú Selda Çimennel, az Észak-ciprusi Török Köztársaság magyarországi főképviselőjével, 2019. július 31., Budapest

20 Türkiye Akdeniz'de neden münhasir ekonomik bölge ilan etmiyor?, [online], 2019. 04. 23. Forrás: Haber Güneș [2019. 07. 30.] 
szerint járó területek egy részét $(1,4,5,6$, 7-es blokk) Ankara saját felségvizének tekinti, és vitatja az Izraellel és Egyiptommal kötött szerződéseket, mondván, hogy a sziget nem járhat el önkényesen a ciprióta törökök megkerülésével ilyen ügyben. 2018. október 31-én Törökország megkezdte a fúrásokat Antalya környékén, még azelött, hogy az Exxon Mobil hozzálátott volna a 10-es blokk feltárásához. November elején pedig Erdoğan a korábbiakhoz hasonlóan megfenyegette a nemzetközi vállalatokat, hogy ne merjenek kutatásokat végezni a ciprusi vizeken. ${ }^{21}$

\section{A jelenlegi földgázlelőhelyek miatti török-ciprusi konfliktus}

A már korábbiakban kifejtett jogi és politikai megfontolások már az első perctől kezdve konfliktushoz vezettek Törökország és Ciprus között. Az első ciprusi licenszszerződés megkötése (2008) után (ezt az amerikai Noble Energy nyerte meg) a térségbe küldött kutatóhajót a török hadihajók tartóztatták fel - ez már elöre jelezte egy komoly konfliktus kialakulásának esélyét. Három évvel később, amikor 2011 szeptemberében a Noble Energy fúróhajót küldött a 12-es blokkba, a török kormány keményen reagált a fejleményre. Ankara nyomban delimitációs egyezményt kötött a KKTC-vel, amelynek kizárólagos gazdasági övezetében a Törökországi Olajvállalat, a TPAO kapta a koncessziós jogokat. Ezzel együtt a TPAO megkezdte az eszközbeszerzést, hogy végre tudja hajtani a tengerfenéket érintő kutatásokat. A vállalat még 2012-ben megvásárolta a Barbarossa Hayreddin Pașára keresztelt szeizmológiai kutatóhajót, amelyet újabbak követtek és ez újabb nemzetközi tiltakozásokhoz vezetett Nicosia részéről.

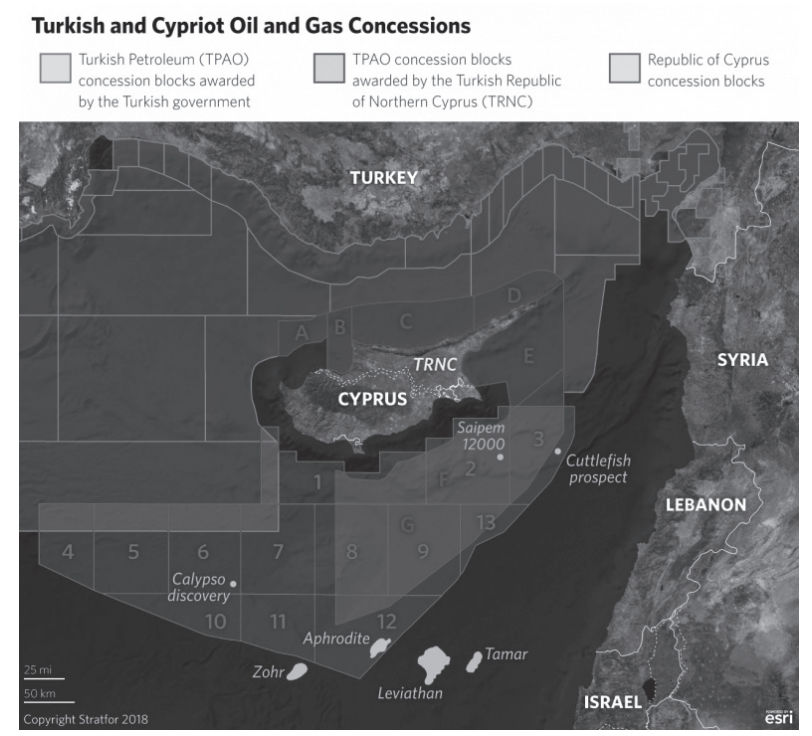

3. ábra: Török és ciprusi földgázkoncessziók és vitatott blokkok

Forrás: Turkish and Cypriot Oil and Gas Concession, [online], 2018. Forrás: ResearchGate [2019. 07. 31.].

${ }^{21}$ Gas in Cyprus: blessing or curse?, [online], 2019. 01. 14. Forrás: Balcanicaucaso.org [2019. 07. 31.] 
A következő években újabb licenszszerződéseket kötöttek a ciprusi görögök, egyelőre csak olyan blokkokban, amelyekre nem vonatkoztak a török követelések. Ugyanakkor Ankara 2014-ben újabb hajót küldött a ciprusi vizekre, szintén hadihajókkal biztosítva. A 2015-17 közötti, tárgyalási időszakban nem történt incidens a vizeken, viszont az év márciusában - nem sokkal az ENI felfedezését követően (Calypso-mező) - Ankara újabb fúróhajót küldött a ciprusi vizekre, amit a ciprusi kormány a szuverenitásának megsértésének könyvelt el. Ezt megelőzően az ENI bejelentése után a 3-as blokkban a vállalat fúróhajóját tartóztatta fel a török haditengerészet, majd kényszerítette azt a visszafordulásra.

A 2019-es év is a régiós energetikai fejleményeknek megfelelően munkásan indult a török fél számára: januárban a Barbarossa hajó újrakezdte a kutatást. Májusban pedig új fúróhajó érkezett a nyugat-ciprusi vizekre, amire Nicosia válasza az volt, hogy elfogatóparancsot adott ki a legénység ellen. Ciprus és Görögország kérésére az uniós válasz sem maradt el. Júniusban az Európai Tanács elítélte a török akciót és a hajók kivonására szólított fel.

Az EU külügyminiszterei július 25-én szankciókat fogadtak el. Az ország 4,454 milliárd eurós előcsatlakozásai alapját 145,8 millió euróval megvágták, leállították a légi szállítási egyezményről szóló tárgyalásokat, illetve más, magas szintü tanácskozásokat. Ezzel együtt pedig a Tanács felhívta az Európai Fejlesztési Bankot, hogy állítsa meg a törökországi hitelezést, amelynek összege tavaly majdnem elérte a 360 millió eurót. ${ }^{22}$

Erre válaszul Ankara kijelentette, hogy az uniós szankciók egyáltalán nem fogják befolyásolni a szénhidrogénkészletek feltárására tett erőfeszítéseit, mivel azok egyrészt a saját, másrészt pedig a ciprusi törökség tulajdonát képezik. ${ }^{23} \mathrm{~A}$ török kormány továbbá jelezte, hogy egy újabb hajót irányít a térségbe a már ott tevékenykedő három mellé. ${ }^{24}$ Úgy tünik azonban, hogy Törökország a sikeres ciprusi fúrások hosszú távú blokkolására nem rendelkezik megfelelő eszközökkel. A nemzetközi környezet nem támogatja ezeket az akciókat, és mivel a nemzetközi közösség a Ciprusi Köztársaságot tekinti a sziget egyetlen államának, nemzetközi jogilag is nagyon korlátozottak Ankara lehetőségei. Ugyanakkor Ankara az utóbbi években jelentős pénzügyi forrásokat fordított egy ütőképes hadiflotta kiépítésére. A déli előterében lévő országok között alakuló energetikai kooperáció - mint láttuk, januárban Kairóban magas szintü fórum szerveződött Törökország kihagyásával - erödemonstrációra késztette az országot. Ennek megfelelően február 27. és március 8. között „Kék haza” (Mavi Vatan) névvel megrendezték az ország modern kori történelmének legnagyobb haditengerészeti gyakorlatát. A Fekete-tengeren, az Égei-tengeren és Földközitengeren zajló akcióban mintegy 103 hadihajó, tengeralattjáró és egyéb hajó, valamint drónok vettek részt. ${ }^{25}$ A gyakorlat során ráadásul az oroszokat is sikerült bevonniuk. ${ }^{26}$ Ezzel párhuzamosan zajlik a flotta fejlesztése is. Már készül, s a várakozások szerint 2020-ra átadják az ország első (kisebb méretű) repülőgép-hordozóját, a TCG Anadolut. ${ }^{27}$ A török

22 EU sanctions Turkey for drilling off the coast of Cyprus, [online], 2019. 07. 16. Forrás: Euroniws.com [2019. 07. 25.]

23 No: 206, 16 July 2019, Press Release Regarding the Conclusions Adopted by the EU Foreign Affairs Council, [online], 2019. 07. 16. Forrás: Mfa.gv.tr [2019. 07. 25.]

24 Dördüncü gemi de gidiyor, [online], 2019. 07. 17. Forrás: Hurriyet.com [2019. 07. 25.]

25 ,Mavi Vatan'daki dev tatbikat göz kamaştırdı, [online], 2019. 03. 07. Forrás: Anadolu Ajansi [2019. 08. 01.]

26 Rusya: Türkiye ile Karadeniz'de ortak tatbikat düzenledik, [online], 2019. 03. 08. Forrás: Aydınlık [2019. 08. 01.]

27 TCG Anadolu Geliyor, [online], 2019. 02. 12. Forrás: Youtube.com [2019. 08. 01.] 
tervek szerint 2023-ra összesen 24 új hajó, köztük négy fregatt fog elkészülni, mindezek hazai gyárakban. ${ }^{28}$

Külpolitikai szinten nem alakult túl biztatóan Törökország pozíciója. Míg a Ciprusi Köztársaság rendezte és többnyire javította kapcsolatát a régió államaival, és a két legnagyobb gázlelőhely birtokosával, Izraellel és Egyiptommal egészen szívélyessé váltak a kapcsolatok és az energetikai együttmüködés felé is megnyílt az út, addig Törökország elszigetelődött. A 2009-es davosi és 2010-es Mavi Marmara flottilla incidens után a korábban jónak mondható viszony megromlott Izraellel, illetve 2013-ban Murszi egyiptomi elnök megbuktatását követően az új egyiptomi kormányzattal vált szintén ellenségessé a kapcsolat. Ugyanakkor a török kormány a szomszédos Szíriától sem számíthat sok jóra.

Ezek a konfliktusok pedig a három ország, Ciprus, Egyiptom és Izrael határvidékén lévő földgázkincs értékesítésére is rányomják bélyegüket. Ankara szerint kézenfekvő és a legolcsóbb megoldás az lenne, ha Törökország felé épített vezetéken keresztül szállítanának gázt az energiaéhes uniós államok felé. Mindez a gazdasági racionalitás mellett kétségkívül előnyös lenne az ország számára: nemcsak hatalmas tranzitbevételekhez juttatná Ankarát és erősítené az energiaelosztó központ szerepét, de maga is fogyasztóként belépve diverzifikálhatná az eddig 50-60\%-ban Oroszországtól függő gázimportját. Nem véletlen, hogy több évnyi fagyos viszony után 2015 végétől, az orosz Szu-24-es lelövése utáni szankciók árnyékában indult meg a török-izraeli kapcsolatok javulása, és került sor kölcsönösen nagykövetek küldésére. ${ }^{29}$ A látványos közeledés nem tartott sokáig, ahogy korábban is, úgy 2018-ban ismét a palesztin-izraeli kapcsolatok miatt romlott meg a két állam kapcsolata, aminek köszönhetően ismét nem delegálnak nagykövetet egymáshoz. ${ }^{30}$ Ezzel párhuzamosan az energetikai együttmüködés is kezdetleges stádiumban maradt.

\section{Mi várható?}

A jelenlegi konfliktus az évek óta húzódó szénhidrogénkincs, illetve tágabb értelemben Ciprus több évtizedes megosztottságának legújabb fejezete. Ankara az elmúlt tíz évben a Kelet-Mediterráneum legtöbb államával „összeveszett” (2009-2010: Izrael, 2011: Szíria, 2013: Egyiptom), így a gazdasági racionalitással szemben kétséges, hogy ezek az államok egy olyan gázvezeték megépítését hagynák jóvá, ami a velük ellenséges vagy éppen megbízhatatlannak ítélt kis-ázsiai államon keresztül vezetne a hőn áhított uniós piacok felé. Emiatt három opció van napirenden: az izraeli-ciprusi felségvizekről Görögország érintésével építendő EastMed gázvezeték terve, amelynek aláírásán 2019 márciusában Mike Pompeo is részt vett, demonstrálva az Egyesült Államok támogatását minden olyan projekt mellett, ami az orosz gáz kiváltását teszi lehetővé Európában. Ráadásul az Európai Bizottság is közös érdekü projektnek nyilvánította a gázvezetéket. Azonban több nehézség is akadályozza

\footnotetext{
28 Turkey is willing to set Eastern Mediterranean on fire. Why now and what lies next..., [online], 2019. 05. 07. Forrás: South East Med Energy@Defense [2019. 08. 01.]

29 Israel, Turkey deepen energy ties as relations resume after 6-yr rupture, [online], 2016. 10. 13. Forrás: Reuters [2019. 07. 30.]

30 Israel decides not to appoint new ambassador to Turkey, [online], 2018. 11. 19. Forrás: Anadolu ajansi [2019. 07. 30.]
} 
a megvalósítását, így például problémaforrást jelenthetnek az együttműködés stabilitása, a piacok nagysága, illetve a nemzetközi viták. ${ }^{31}$

A második opció, hogy Ciprus maga épít egy LNG-terminált - azonban ennek költségei és a valóban kitermelhető földgázkincs nagysága kérdésessé teszi ennek realitását.

Nagy valószínüséggel a már müködő egyiptomi LNG-terminálokhoz vivő vezetékeket választják a régiós kormányok. Így például a ciprusi-egyiptomi gázvezetékről 2018 őszén megállapodást is írtak alá. ${ }^{32}$

Törökország céljai világosak: biztosítani magának a saját kontinentális talapzatához, illetve ezzel együtt az Észak-ciprusi Török Köztársasághoz tartozó területek alatt megbúvó természeti kincsek kitermelésének jogát. Mindezt a komoly diplomáciai és nemzetközi jogi aggályok, a térség szinte összes államának tiltakozásának ellenére. A török politika ezen célok mentén alapvetően reaktívan alakult: a ciprusi (esetleg régiós) lépésekre adott válaszként küldött kutatóhajókat vagy hadihajókat a fennhatósága alatti vizekre. Az utóbbi hónapok erődemonstrációi is ezt a célt szolgálják: a felgyorsuló kelet-mediterráneumi együttmüködésre és folytatódó ciprusi kutatásokra nyomást gyakorolni, megvédeni a török és észak-ciprusi érdekeket, miközben késleltetni a nemzetközi cégek fúrásait, kutatásait, ezzel is jobb pozíciót kiharcolva a tárgyalásokhoz.

Ankara viszont nemcsak a terepen igyekszik erőt mutatni, hanem a kialakuló héthatalmi szövetség mellé saját szövetségeseket keres. Ebben a helyzetben jelenleg négy entitás jöhet szóba: az Izraellel területi vitákat folytató Libanon, a Görögország és Egyiptom hátában lévő Líbia, valamint a viszonylagos autonómiával rendelkező Gáza, amely szintén rendelkezik egy kis területü tengeri kijárattal. Ankara támogatásáról biztosította Bejrútot, és mivel Libanon nem ratifikálta a delimitációs szerződést Ciprussal, emiatt ezzel valóban segíti Törökország pozícióit. Líbia szintén fontos szereppel bír Ankara terveiben, azonban úgy tünik, hogy ott sem sikerült megtalálni a megfelelö szövetségest. ${ }^{33}$

A török akciókra adott uniós szankciók szerények, a törökök törekvéseit kevésbé fogják korlátozni. Az amúgy sem túl jelentős pénzügyi források korlátozása - ahogy erre már 2018-ban is láthattunk példát - újabb éket vernek az EU és Törökország kapcsolatába, de nem képes olyan fenyegetéssé válni, ami meghátrálásra késztetné a török kormányt. Ankarára csak gazdasági szankciókkal lehetne nyomást gyakorolni, akkor is csak abban az esetben, ha a komolyabb uniós partnereitől vágná el az országot, ahogy 2017 közepén Berlin ezt belengette. ${ }^{34}$ Azonban a ciprusi ügy kapcsán egyik nagyobb uniós államnak sem érdeke túlfeszítenie a húrt, különösen annak a fényében, hogy Törökország területén hivatalosan 3,5 millió szíriai menekült található - a valóságban ennél többről van szó -, és akiknek a Görögországba és Bulgáriába történő átkelését Törökország hatékonyan akadályozza a 2016 első felében életbe léptetett mechanizmusnak köszönhetően. Nem

31 Nikos Stafos: Can the East Med Pipeline Work?, [online], 2019. 01. 22. Forrás: CSIS [2019. 08. 01.]

32 Cyprus Pipeline Deal With Egypt Brings Gas Step Closer to Europe, [online], 2018. 09. 19. Forrás: Bloomberg [2019. 08. 01.]

33 Metin GÜRCAN: Libya has outsized importance for Turkey's Mediterranean plans, [online], 2019. 07. 05. Forrás: Al-Monitor [2019. 08. 02.]

34 EGEREsi Zoltán: Merre tovább? A német-török kapcsolatok 2017-es német választás után, [online], 2017. 10. 06. Forrás: SVKK Elemzések [2019. 08. 02.] 
véletlen, hogy a szíriai menekültek integrációját érintő uniós milliárdokat nem csonkították meg az uniós vezetők.

A másik hatalom, amely hatni tudna Ankarára, az Egyesült Államok, amely szintén érdekelt a térség gázlelőhelyeinek kitermelésében, valamint ezzel együtt a rend fenntartásában a saját szövetségesei között. A törökök számára jelzésértékủ volt az utóbbi hónapok görög-ciprusi-izraeli és amerikai közeledése. ${ }^{35}$ Ugyanakkor, ahogy az elmúlt évtizedek megmutatták, Washington a ciprusi konfliktus kapcsán alig tudott hatni görög és török szövetségeseire (az 1963-as Johnson-levél sikere inkább kivételesnek tekinthető, ráadásul komoly szerepe volt abban, hogy néhány időszakot leszámítva mélyrepülésbe kezdjenek a bilaterális kapcsolatok). A helyzetet tovább bonyolítja, hogy számos kényes kérdés feszíti az amerikai-török kapcsolatokat (Szíria, S-400-as vásárlás), amelyekhez képest ez a probléma harmad- vagy negyedrangúnak tünik. ${ }^{36}$ Ráadásul a térségben szintén érdekelt Oroszország - amely ugyan elítélte a török akciót - nem nézi rossz szemmel a NATO-n belül kialakuló feszültséget. Törökország különutassága a szövetségen belül egyre több konfliktust szül, azonban eddig a legtöbb kérdésben Ankara követi a NATO-s irányelveket és célkitűzéseket. ${ }^{37}$

Így marad a patthelyzet, s ezzel együtt a török fúróhajók folytatják majd a kutatást, lehetőség szerint biztos távolságban a dél-ciprusi partoktól, hogy elejét vegyék egy komolyabb diplomáciai konfliktus kialakulásának. Viszont a török vagy észak-ciprusi tengeri övezetben talált természeti kincsek későbbi kitermelésében nem nagy beleszólása lesz a görög ciprióta szigetrésznek - ahogy megegyezés nélkül a déli területekből származó jövedelemre sem számíthatnak az északiak. Az egyesítési tárgyalások jelenleg állnak, s ilyen környezetben nem valószínű, hogy hamar folytatódni fognak. A jelenlegi érdekszféra-kijelölésben újabb fejezetet nyithat, amennyiben kiderül, hogy a mindkét fél által magának követelt területeken nincs lelöhely, hiszen ebben az esetben a komolyabb konfliktus elkerülhetö. Viszont ha a török kutatóhajók sikerrel járnak a következő években, az egyre erősödő török flotta képes lesz megörizni ezeket a területeket, s biztosítják a török fennhatóságot Ciprussal szemben, ami újra csavar egyet a két szigetrész egyesítésének ügyén.

\section{FELHASZNÁLT IRODALOM}

Bechev, Dimitar: Greece Is Getting Good at Geopolitics, [online], 2019. 07. 25. Forrás: Foreign Policy [2019. 08. 01.]

Blessing or curse for the divided island? [online], 2018. 12. 21. Forrás: Voxeurop [2019. 01. 12.].

Constitution of Cyprus 1960, [online]. Forrás: UNPan1 [2019. 08. 03.]

Cyprus Pipeline Deal With Egypt Brings Gas Step Closer to Europe, [online], 2018. 09. 19. Forrás: Bloomberg [2019. 08. 01.]

35 Gökhan GüLER: Doğu Akdeniz ve Ege’deki Gasp ile Çatışma Girişimleri, [online], 2019. 06. 29. Forrás: Türksam [2019. 08. 03.]

36 A Törökország és USA közötti viszony romlásáról lásd: EgEREsı Zoltán: Konfliktusok az amerikai-török kapcsolatokban, [online], 2018/7. Forrás: SVKK Elemzések [2019. 08. 02.]

37 PÉNZvÁLTó Nikolett: Törökország és a NATO viszonya 1991-től napjainkig, [online], 2018/18. Forrás: SVKK Elemzések [2019. 08.02.] 
Cyprus reunification talks collapse, U.N. chief,very sorry', [online], 2017. 07. 07. Forrás: Reuters [2019. 07. 25.]

Dördüncü gemi de gidiyor, [online], 2019. 07. 17. Forrás: Hurriyet.com [2019. 07. 25.]

Eastern Mediterranean countries to form regional gas market, [online], 2019. 01. 14. Forrás: Reutres [2019. 07. 31.]

EgERESI Zoltán: Merre tovább? A német-török kapcsolatok 2017-es német választás után, [online], 2017. 10. 06. Forrás: SVKK Elemzések [2019. 08. 02.]

EGERESI Zoltán: Konfliktusok az amerikai-török kapcsolatokban, [online], 2018/7. Forrás: SVKK Elemzések [2019. 08. 02.]

Egypt Looks to Offshore Gas Field for Growth and Influence, [2019. 03. 11.]. Forrás: The New York Times [2019. 07.30.]

Egypt to supply Kingdom with half of its gas needs this year, [2019. 01. 13.]. Forrás: Jordan Times [2019. 07.30.]

Eni made important gas discovery in block 6 (updated), [online], 2018. 02. 08. Forrás: Cyprus Mail [2019. 07. 29.]

EU sanctions Turkey for drilling off the coast of Cyprus, [online], 2019. 07. 16. Forrás: Euroniws.com [2019. 07. 25.]

Exxon's Cyprus gas discovery adds another giant to East Med collection, [online], 2019. 02. 28. Forrás: Reuters [2019. 07.31.]

Gas in Cyprus: blessing or curse?, [online], 2019. 01. 14. Forrás: Balcanicaucaso.org [2019. 07. 31.]

GürCAN, Metin: Libya has outsized importance for Turkey's Mediterranean plans, [online], 2019. 07. 05. Forrás: Al-Monitor [2019. 08. 02.]

Israel decides not to appoint new ambassador to Turkey, [online], 2018. 11. 19. Forrás: Anadolu ajansi [2019. 07. 30.]

Israel will start exporting natural gas to Egypt this year, [online], 2019. 07. 25. Forrás: Aljazeera [2019. 08. 01.]

Israel, Turkey deepen energy ties as relations resume after 6-yr rupture, [online], 2016. 10. 13. Forrás: Reuters [2019. 07.30.]

Israel: Differing opinions on the Leviathan field size, [online], 2016. 06. 06. Forrás: Offshoreenergytoday.com [2019. 07.31.]

KACzıBA Péter: A ciprusi földgázkincs feltárásának bel- és külpolitikai sajátosságai, Külügyi Szemle, 12. évf., 2013/4, 149-171. o.

KaCzıiA Péter: Többség kisebbségi, kisebbség többségi támogatással: Az anyaországi beavatkozás szerepe Cipruson. In: Szalai Máté - Wagner Péter: A többség-kisebbség dinamika szerepe a közel-keleti konfliktusokban, Magyarország: Külügyi és Külgazdasági Intézet, Budapest, 2019, 58-80. o.

'Mavi Vatan'daki dev tatbikat göz kamaştırdı, [online], 2019. 03. 07. Forrás: Anadolu Ajansi [2019. 08. 01.]

No: 206, 16 July 2019, Press Release Regarding the Conclusions Adopted by the EU Foreign Affairs Council, [online], 2019. 07. 16. Forrás: Mfa.gv.tr [2019. 07. 25.]

Rusya: Türkiye ile Karadeniz’de ortak tatbikat düzenledik, [online], 2019. 03. 08. Forrás: Aydınlık [2019. 08. 01.]

PÉNZvÁLTó Nikolett: Törökország és a NATO viszonya 1991-től napjainkig, [online], 2018/18. Forrás SVKK Elemzések [2019. 08. 02.]

Significant natural gas discovery made off israel's shore, [online], 2019. 05. 15. Forrás: Jerusalem Post [2019. 07. 31.]

Stafos, Nikos: Can the East Med Pipeline Work?, [online], 2019. 01. 22. Forrás: CSIS [2019. 08. 01.]

TCG Anadolu Geliyor, [online], 2019. 02. 12. Forrás: Youtube.com [2019. 08. 01.]

Turkey is willing to set Eastern Mediterranean on fire. Why now and what lies next..., [online], 2019. 05. 07. Forrás: South East Med Energy@Defense [2019.08. 01.

Turkey, Cyprus: The Eastern Mediterranean Heats Up Over Drilling, [online], 2019. 05. 07. Forrás: Stratfor [2019. 07. 30.]

Turkish and Cypriot Oil and Gas Concession, [online], 2018. Forrás: ResearchGate [2019. 07. 31.]

Türkiye Akdeniz’de neden münhasir ekonomik bölge ilan etmiyor?, [online], 2019. 04. 23. Forrás: Haber

Güneș [2019. 07. 30.] 